Abstracta Iranica Abstracta Iranica

Revue bibliographique pour le domaine irano-aryen

Volume 22 | 2001

Comptes rendus des publications de 1999

\title{
The Index of al-Manar. Beyrouth - Turath - Tokyo, The Islamic Area Studies Project, 1998, x1-418-2 p.
}

\section{Stéphane A. Dudoignon}

\section{OpenEdition}

1 Journals

\section{Édition électronique}

URL : http://journals.openedition.org/abstractairanica/36763

DOI : 10.4000/abstractairanica.36763

ISSN : 1961-960X

Éditeur :

CNRS (UMR 7528 Mondes iraniens et indiens), Éditions de l'IFRI

\section{Édition imprimée}

Date de publication : 15 mai 2001

ISSN : 0240-8910

Référence électronique

Stéphane A. Dudoignon, « The Index of al-Manar. Beyrouth - Turath - Tokyo, The Islamic Area Studies Project, 1998, xI-418-2 p. », Abstracta Iranica [En ligne], Volume 22 | 2001, document 337, mis en ligne le 17 février 2010, consulté le 13 octobre 2020. URL : http://journals.openedition.org/abstractairanica/ 36763 ; DOI : https://doi.org/10.4000/abstractairanica.36763

Ce document a été généré automatiquement le 13 octobre 2020.

Tous droits réservés 


\title{
The Index of al-Manar. Beyrouth - Turath - Tokyo, The Islamic Area Studies Project, 1998, x1-418-2 p.
}

\author{
Stéphane A. Dudoignon
}

Grâce à sa richesse et à la quantité de ses entrées géographiques, cet index de la revue égyptienne al-Manâr (1898-1935), éditée au Caire par Rašîd Ridâ, disciple de Muhammad 'Abduh, constitue un outil de travail précieux pour tous ceux qu'intéresse l'histoire des relations extrêmement diverses entretenues, pendant le premier tiers du $20^{\mathrm{e}} \mathrm{s}$., entre, d'une part, les milieux intellectuels du monde sunnite persanophone et türkophone (Afghanistan et Asie centrale, en particulier), et d'autre part Le Caire, l'un des principaux foyers de pensée modernistes du monde musulman au tournant de ce siècle.

\section{INDEX}

Thèmes : 7. Islam

\section{AUTEURS}

STÉPHANE A. DUDOIGNON

CNRS - Strasbourg 